\title{
Molecular Characterization of Heat Shock Protein 70-1 Gene of Capra aegagrus blythi
}

\author{
Fehmeeda Fatima, Asif Nadeem* and Maryam Javed \\ Institute of Biochemistry and Biotechnology, University of Veterinary and Animal \\ Sciences, Lahore 54000, Pakistan
}

Fehmeeda Fatima and Asif Nadeem contributed equally to this article.

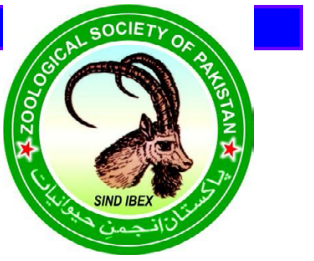

CrossMark

\begin{abstract}
A B S T R A C T
Sindh ibex (Capra aegagrus blythi) is a vulnerable subspecies of wild goat (Capra aegagrus), which faced serious population threats. In the present study, HSP70.1 gene has been partially sequenced (1344 bp) to study genetic diversity and evolutionary characteristics of Sindh ibex. In this research, samples of Sindh ibex were collected from Kirthar National Park, Sindh, Pakistan, the gene of interest was amplified, PCR products were sequenced and data was analyzed. The results of genetic diversity indicated that Parsimony informative sites were found to be 11 while Singleton variable sites were not detected. The total number of haplotypes (h) was found to be 17 and haplotype diversity (Hd) was 0.862 . Nucleotide diversity (pi) was calculated to be 0.00210 and Tajima's $D$ neutrality test for neutral mutation indicated a negative value. Moreover, the results of homology analysis showed maximum similarity with sequences of goat and sheep sequences (partial) and were found to be $99.93 \%$ and $99.35 \%$, respectively which was further confirmed by constructing phylogenetic tree which indicated that Sindh ibex, domestic goat, and sheep share a common ancestor.
\end{abstract}

Article Information
Received 19 March 2018
Revised 23 April 2018
Accepted 05 June 2018
Available online 06 December 2018
Authors' Contribution
AN conceived and designed the study.
AN and FF did sampling, genome
extraction, amplified the markers
and wrote the article. MJ analyzed
the data.
Key words
Heat shock protein, Genetic diversity,
Polymorphisms, Phylogenetic analysis,
Sindh ibex.

Article Information

Revised 23 April 2018

Accepted 05 June 2018

Available online 06 December 2018

gned the study.

AN and FF did sampling, genome

and wrote the article.

the data.

Sindh ibex.

\section{INTRODUCTION}

$\mathrm{S}$ indh ibex (Capra aegagrus blythi) is a vulnerable subspecies of wild goat (Capra aegagrus) which is scattered among arid mountain ranges of Pakistan, including low Mekran coastal range, the Koh-i-Maran range south of Quetta (District Kalat), and also the Kirthar range (District Dadu and Las Bela) (Shackleton, 1997). According to Yamada et al. (2004), the population of Sindh ibex faced a serious decline due to massive hunting by humans and dropped to 200 goats in Kirthar National Park before the conservation plan was started in 1967. As the habitat suggests, Sindh ibex lives in a very harsh environment, where it experiences various stress situations including nutritional decline, physical and psychological stress, climate change, and thermal stress.

Heat Shock Proteins (HSP) are one of the most important biomolecules involved in thermoregulation during stress conditions (Ravaschiere et al., 2017; Datta et al., 2017). They are chaperones and are produced as a result of increased expression of mRNA of HSPs due to activation of heat shock transcription factor 1 in the cells (Sharma et al., 2013). They are found in every cell of all organisms and are involved in a variety of functions

\footnotetext{
Corresponding author: asifnadeem@uvas.edu.pk 0030-9923/2019/0001-0195 \$ 9.00/0

Copyright 2019 Zoological Society of Pakistan
}

including folding/unfolding of protein, cell signaling, protein transport into subcellular compartment, inhibition of caspase activation to prevent apoptosis and regulator of immune response (Hendrick and Hartl, 1993; Parsell and Lindquist, 1993; Karlin and Brocchieri, 1998; Feder and Hofmann, 1999; Li and Srivastava, 2004; Schmitt et al., 2007; Zuo et al., 2016; Chatterjee and Burns, 2017; Edkins et al., 2018). They are highly conserved in almost all species (Karlin and Brocchieri, 1998; Li and Srivastava, 2004) with HSP 70 as the most conserved proteins in the evolutionary lineage (Gupta and Singh, 1994; Daugaard et al., 2007).

The HSP $70 \mathrm{kDa}$ is one of the highly produced HSPs during thermal stress. It serves as an ideal marker in the animal studies for the quantification stress induced by environmental heat (Archana et al., 2017; Dang et al., 2018). This protein is encoded by a family of four genes in bovine. This family includes HSP70-1, HSP70-2, HSP703, and HSP70-4 genes which are expressed under different stress conditions. Expression of HSP70-1gene, however, plays a major role during heat stress in goats. HSP701 gene-which is located on chromosome 23 in bovine species-consists of single exon and has the size of 1926 nucleotide in goats (Gade et al., 2010). Due to its prime role in stress conditions, HSP70 has been studied widely in caprine species (Pawar et al., 2013; Romero et al., 2013; Banerjee et al., 2014). HSP70-1 has not been studied in Sindh ibex before. The molecular characterization of this 
gene and its comparison with that of the other animals will provide a road map for the better understanding of the gene pools of the wild goat to plan a better strategy for conservation and management.

\section{MATERIALS AND METHODS}

\section{Sample collection and DNA isolation}

Blood/meat samples $(\mathrm{n}=25)$ of wild goats (Capra aegagrus blythi) were collected from Kirthar National Park, Sindh, Pakistan. Meat samples were also collected and stored in $70 \%$ ethanol. Blood of hunted animals was collected into vacutainers containing ethylenediamine tetra acetic acid (EDTA) as an anticoagulant and was stored at $-20^{\circ} \mathrm{C}$ before extraction. DNA extraction was done through standard organic extraction method for genomic DNA and then was checked for quality and quantity by agarose gel electrophoresis and Thermo scientific 2000 nano spectrophotometer. The samples were dilute dup to $50 \mathrm{ng} / \mu \mathrm{L}$ for polymerase chain reaction (PCR).

\section{PCR amplification of HSP70-1 gene}

For partial amplification of HSP70-1 gene in Sindh ibex, two sets of overlapping primers were designed using primer 3 software. The HSP70-1 partial gene sequence (1344 bp) of the domestic goat was aligned with chromosome 23 sequence of goat available on NCBI (GenBank: CM001732.2) and then chromosomal sequence was used for primer designing. The primers used include: HSPF1 5'GTGACGTTCAGGATGCCATT3', HSPR1 5'GGCATCTTCGAGGTGAAGG3', HSPF2 5'TGTTCTGGCTGATGTCCTTCT3', and HSPR2 5'ATCATCGCCAACGACCAG3'. PCR conditions were optimized for both primer sets. The $25 \mu \mathrm{L}$ reaction mixture for PCR contained 50ng/ $\mu \mathrm{L}$ DNA, 10X Taq polymerase assay buffer $\left(750 \mathrm{mM}\right.$ Tris- $\mathrm{HCl}$ with $\mathrm{pH} 8.8$ at $25^{\circ} \mathrm{C}, 200$ $\mathrm{mM}\left(\mathrm{NH}_{4}\right)_{2} \mathrm{SO}_{4}, 0.1 \%(\mathrm{v} / \mathrm{v})$ Tween 20$), 25 \mathrm{mM} / \mu \mathrm{L} \mathrm{MgCl}_{2}$, $2.5 \mathrm{mM} / \mu \mathrm{L}$ dNTPs, $10 \mathrm{mM} / \mu \mathrm{L}$ of each primer, and $3 \mathrm{U} / \mu \mathrm{L}$ Taq Polymerase. The conditions for thermocycler were as: initial denaturing at $950^{\circ} \mathrm{C}$ for $5 \mathrm{~min}$ followed by 35 cycles with denaturation at $94^{\circ} \mathrm{C}$ for 30 seconds, annealing of primers at $64^{\circ} \mathrm{C}-52^{\circ} \mathrm{C}$ for 30 seconds and extension for one minute at $72^{\circ} \mathrm{C}$ and then followed by final extension for 10 min at $72^{\circ} \mathrm{C}$. After PCR, the amplicons were checked for specificity by resolving the products on $1.2 \%$ agarose gel along with molecular weight marker.

\section{Sequencing and analysis of PCR products}

PCR products were purified for any non-specification by precipitating them with $100 \mu \mathrm{l}$ of $80 \%$ ethanol. After precipitation, amplicons were sequenced through chain termination method. The sequencing was done bi- directionally by Big Dye ${ }^{\mathrm{TM}}$ Terminator on ABI $3130 \mathrm{XL}$ Genetic analyzer. The sequences were then analyzed using BioEdit software version (V.7.0) (Hall, 1999) and Nucleotide BLAST program available at NCBI website (http://www.ncbi.nlm.nih.gov/BLAST) for seeking similarity with the domestic goat (Altschul et al., 1990). Any change in the DNA sequence was confirmed by sequencing both sense and antisense strands. Percentage similarity was calculated using MUSCLE (Edgar, 2004). To evaluate the polymorphism in the sequences, DNASP v.5 (Librado and Rozas, 2009) was used. Molecular Evolutionary Genetics Analysis (MEGA V.6.0) (Tamura et al., 2013) was used to estimate the evolutionary distances between sequences by computing the of nucleotide differences between each pair of sequences and to construct the phylogenetic trees.

\section{RESULTS}

\section{PCR amplification and sequencing}

PCR amplification was carried out for both the primer sets (IbF1, IbR1; IbF2, IbR2) and the resulting products were sequenced. The results of sequencing were analyzed by performing multiple sequence alignment and BLAST. Nine variations were identified in the partial sequence of HSP70-1 gene (Table I). The analysis showed that all individuals were found to contain polymorphism. Two of all variations were transversion type while the remaining were transition types.

Table I.- Nucleotide sequence variations found in HSP70.1 partial gene of Sindh ibex.

\begin{tabular}{lc}
\hline Polymorphism type (wild $>$ mutant) & Nucleotide position \\
\hline Transition $(\mathrm{G}>\mathrm{A})$ & 27516397 \\
Transition $(\mathrm{G}>\mathrm{A})$ & 27516490 \\
Transversion $(\mathrm{C}>\mathrm{A})$ & 27517282 \\
Transition $(\mathrm{G}>\mathrm{A})$ & 27517273 \\
Transition $(\mathrm{G}>\mathrm{A})$ & 27517255 \\
Transversion $(\mathrm{C}>\mathrm{A})$ & 27517249 \\
Transition $(\mathrm{G}>\mathrm{A})$ & 27517285 \\
Transition $(\mathrm{G}>\mathrm{A})$ & 27517228 \\
Transition $(\mathrm{C}>\mathrm{T})$ & 27517225 \\
\hline
\end{tabular}

\section{Polymorphism analysis}

Polymorphism analysis of the sequences was carries out and variable (polymorphic/segregating) sites (S) and total number of mutations (Eta) were found to be 11 (Table II). Parsimony informative sites were found to be 11 while Singleton variable sites were not detected in the sequences. The $\mathrm{G}+\mathrm{C}$ content was found to be 
0.646 (Table IV). The average number of nucleotide differences (k) was calculated to be 2.82154 (Table III). Considering the variance of $\mathrm{k}$ (for both recombination and non-recombination), the stochastic errors were found to be more dominant towards total variance than were the sampling variance (Tajima, 1983). This shows that various factors are involved in the difference of $\mathrm{k}$ values among the individuals. Moreover, sequence conservation value was found to be 0.992 (Table IV).

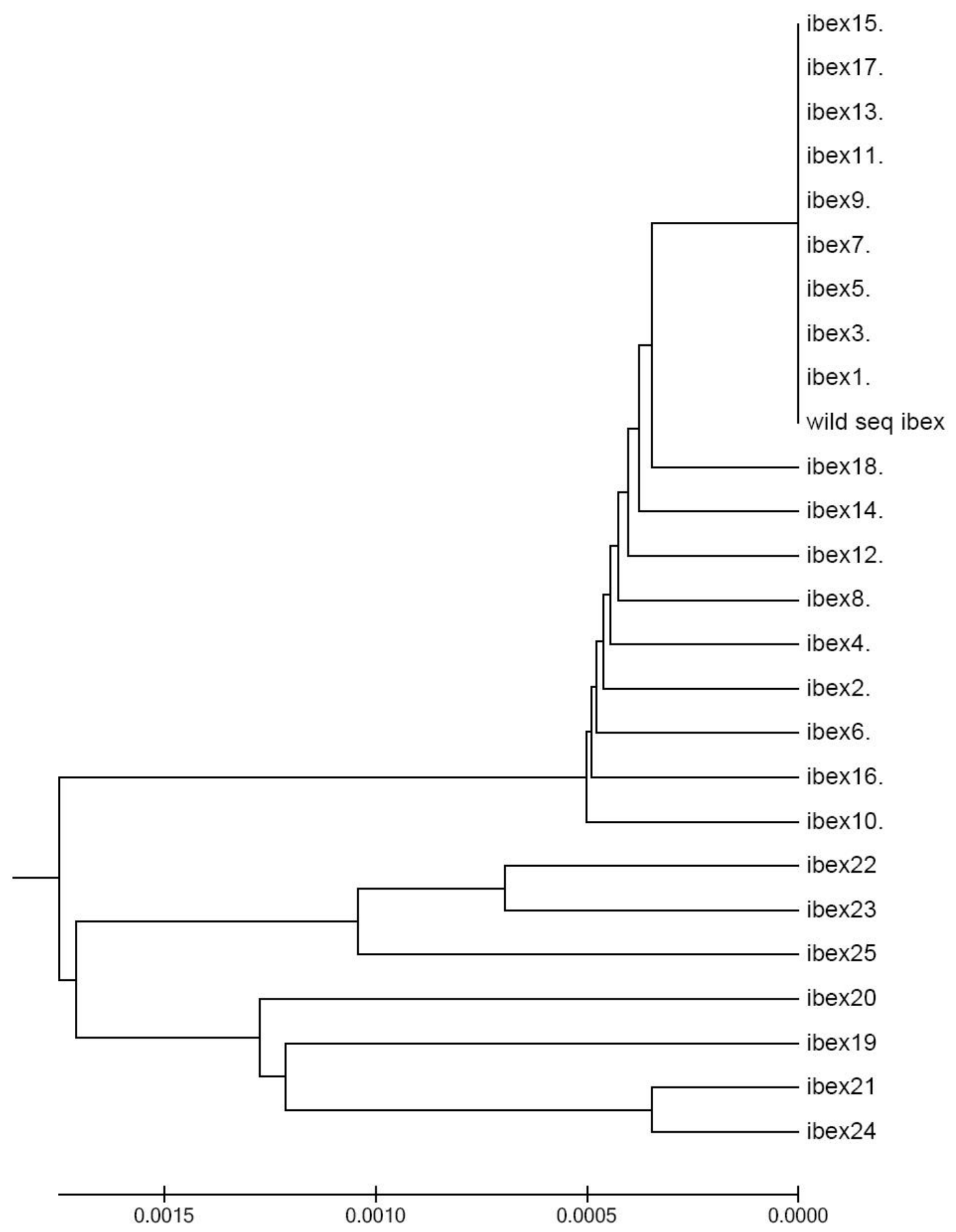

Fig. 1. UPGMA phylogenetic tree made on the basis of HSP70.1 gene sequences of Sindh ibex after alignment using clastal W program. 
Table II.- Polymorphic sites in HSP70.1 gene of Sindh ibex.

\begin{tabular}{lc}
\hline Type of sites & $\begin{array}{c}\text { Number of } \\
\text { sites }\end{array}$ \\
\hline Sites with alignment gaps or missing data & 0 \\
Invariable (monomorphic) sites & 1333 \\
Variable (polymorphic/segregating) sites (S) & 11 \\
Total number of mutations (Eta) & 11 \\
Singleton variable sites & 0 \\
Parsimony informative sites & 11 \\
Singleton variable sites (two variants) & 0 \\
Parsimony informative sites (two variants) & 11 \\
Site positions & $610,342,345$, \\
& $354,372,378$, \\
& $399,402,1137$, \\
Variable sites (three variants) & 1230 \\
Variable sites (four variants) & 0 \\
\hline
\end{tabular}

The total number of haplotypes (h) was found to be 17 and haplotype diversity (Hd) was estimated to be 0.862 (Table III). Nucleotide diversity (pi) was calculated to be 0.00210 . Tajima's $D$ neutrality test for neutral mutation indicated the negative value.

\section{Homology analysis and phylogenetics}

Results of homology analysis indicated that HSP 70.1 gene partial sequence of Sindh ibex showed maximum similarity with that of goat and sheep sequences (partial) and was found to be $99.93 \%$ and $99.35 \%$ (Fig. 2). The phylogenetic tree showed a close evolutionary relationship of Sindh ibex with goat and sheep (Fig. 3).
Table III.- Haplotype and nucleotide diversity.

\begin{tabular}{lc}
\hline Character & Value \\
\hline Number of Haplotypes (h) & 17 \\
Haplotype (gene) diversity (Hd) & 0.862 \\
Variance of Haplotype diversity & 0.00463 \\
Standard Deviation of Haplotype diversity & 0.068 \\
Nucleotide diversity (per site) (Pi) & 0.00210 \\
Sampling variance of Pi & 0.0000001 \\
Standard deviation of Pi & 0.00036 \\
Average number of nucleotide differences (k) & 2.82154 \\
Stochastic variance of k (no recombination), Vst(k) & 2.184 \\
Sampling variance of k (no recombination), Vs(k) & 0.180 \\
Total variance of k (no recombination), V(k) & 2.365 \\
Stochastic variance of k (free recombination), & 0.941 \\
Vst(k) & \\
Sampling variance of k (free recombination), Vs(k) & 0.075 \\
Total variance of k (free recombination), V(k) & 1.016 \\
Tajima's D & -0.07043 \\
& (not significant, \\
\hline
\end{tabular}

Table IV.- Sequence conservation.

\begin{tabular}{lc}
\hline Character & Value \\
\hline Net number of analyzed sites (L) & 1344 \\
Number of variable/polymorphic sites (S) & 11 \\
Sequence conservation (C) & 0.992 \\
G+C content & 0.646 \\
& $(1344.00$ sites $)$ \\
\hline
\end{tabular}

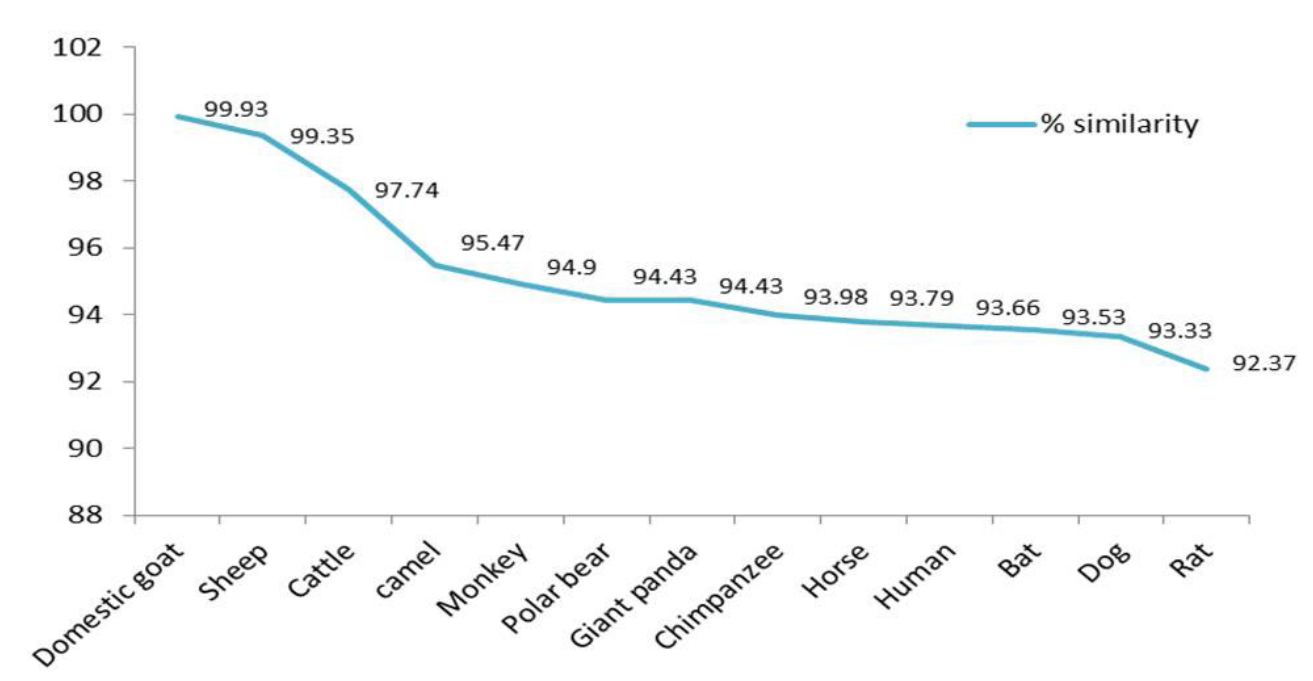

Fig. 2. Homology analysis of HSP70.1 gene of Sindh ibex with that of other animals by using MUSCLE alignment tool. 


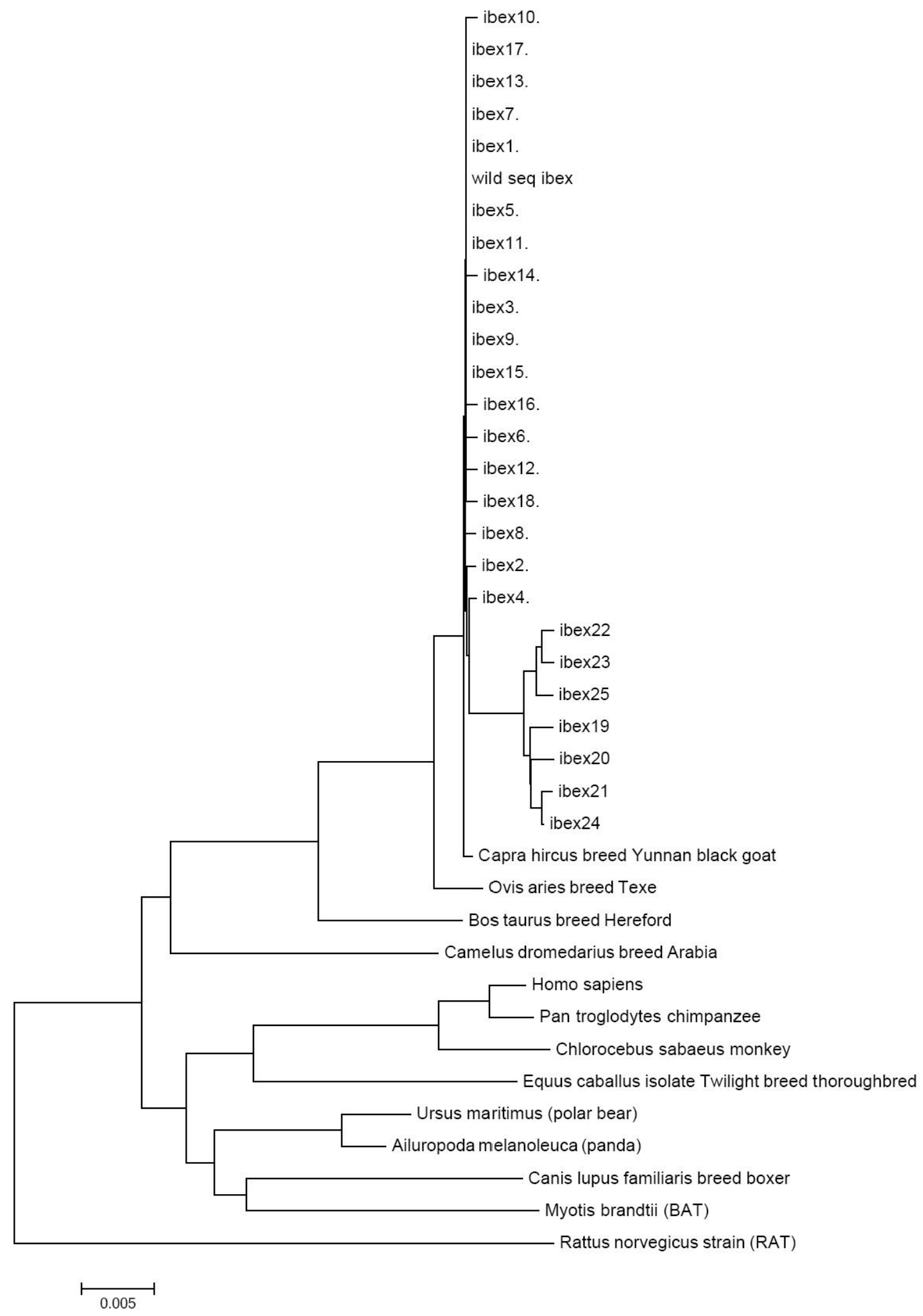

Fig. 3. Neighbor joining phylogenetic tree made on the basis of HSP70.1 gene sequences of Sindh ibex and other species after alignment using clastal $\mathrm{W}$ program. 


\section{DISCUSSION}

\section{DNA polymorphism analysis}

DNA polymorphism data provides important information about the structure and evolutionary history of a population and species and about the relationship between various populations and species. It plays a vital role in the fields of conservation genetics, animal and plant breeding and epidemiology genetics (Rozas et al., 2003). Phylogenetic analysis of Pakistani livestock breeds such as buffalo, goat, sheep, camel (Babar et al., 2014, 2015; Hussain et al., 2009, 2013a, b, 2015; Ahmed et al., 2014) have previously been reported but wildlife species data is limited. Therefore our study describes, for the first time, polymorphism data on Sindh ibex, which is a vulnerable species, on the basis of HSP70.1 gene. HSP70 has been studied before for the genetic analysis of chicken (Gan et $a l ., 2015$ ). The results of our study showed high haplotype diversity in the population of Sindh ibex at Kirthar National Park. However, the nucleotide diversity was found to be low. Similar results have been in found in the wild populations of many species (Jiang et al., 2005; Wu and Fang, 2005; de Jong et al., 2011; Langille et al., 2014). Low nucleotide diversity and high haplotype diversity indicates that population has expanded rapidly and has survived a recent bottleneck (de Jong et al., 2011).

Further, the neutrality tests were performed to test the neutral theory of evolution (Kimura, 1984). According to this theory, most of the variations at the molecular level are neutral and random drift of selectively neutral or nearly neutral mutants are the cause of most of the evolutionary occasions. To test this theory various tests statistics are applied. Tajima's D test is one of the most popular tests. It assumes that mutation and random genetic drift are the major cause of evolutionary change. The results indicated negative value. This suggests that the population of Sindh ibex experienced severe bottleneck with successive expansion phase at present which is consistent with polymorphism data. The negative value of a Tajima's D test, however, was insignificant which specifies that the population contains neutral mutations and highlights the genetic drift as the mode of evolution rather than positive or direct selection (Tajima, 1989) as compared to results found in domestic goat which indicated the positive selection as the mode of evolution (Gade et al., 2010; Pawar et al., 2013). However, the main factor influencing the evolutionary difference was found to be the population status of Sindh ibex as compared with that of the domestic goat which has larger and better-maintained populations. Neutral mutations were also confirmed when deduced amino sequence of HSP70-1 protein of Sindh ibex samples was compared with that of the wild sample. All of the nucleotide variations were found to be synonymous.

\section{Homology analysis and phylogenetics}

The sequences of HSP70-1 gene of Sindh ibex were aligned and compared for phylogenetic analysis. The pairwise genetic distance was computed and the average was found to be 0.002 . The phylogenetic tree was constructed which showed less diversity among the population and high similarity between individuals shown in Figure 1.

Results of homology analysis indicated that HSP701 gene of Sindh ibex is highly homologous to that of other organisms (Fig. 2) as studied by Gade et al. (2010), Banerjee et al. (2014), Gupta et al. (2015) and Kumar et al. (2015). The similarity with cattle and camel was found to be $97 \%$ and $95.4 \%$, respectively. Moreover, Sindh ibex HSP70-1 sequence showed $95 \%$ similarity with that of human, dog, horse, monkey, chimpanzee, giant panda, polar bear, rat, and bat. Further, the phylogenetic tree showed a close evolutionary relationship of Sindh ibex with goat and sheep (Fig. 3). Similar results were found by Gade et al. (2010), who indicated higher homology of goat HSP 70.1gene with that of cattle, buffalo, yak, sheep (partial), pig, horse, and humans. This indicates that Sindh ibex, goat, cattle, buffalo and sheep evolved from a common ancestor.

\section{CONCLUSION}

This study was carried out in an effort of exploring the effects of stress factors on survival and diversity of Sindh ibex. As this animal faced serious population threats, our results will provide the first step to study its population structure and diversity and the evolutionary pathways. Moreover, large sample size and the use of various molecular markers is required to fully explore the genetic pool of Sindh ibex to better understand and plan more effective conservation strategies for Sindh ibex and other wildlife of Pakistan.

\section{Statement of conflict of interest}

Authors have declared no conflict of interest.

\section{REFERENCES}

Ahmed, Z., Babar, M.E., Hussain, T., Nadeem, A., Awan, F.I., Wajid, A., Shah, S.A. and Ali, M.M., 2014. Genetic diversity analysis of Kail sheep by using microsatellite Markers. J. Anim. Pl. Sci., 24: 1329-1333.

Altschul, S.F., Gish, W., Miller, W., Myers, E.W. and Lipman, D.J., 1990. Basic local alignment search 
tool. J. mol. Biol., 215: 403-410. https://doi. org/10.1016/S0022-2836(05)80360-2

Archana, P.R., Aleena, J., Pragna, P., Vidya, M.K., Niyas, A.P.A., Bagath, M. and Kurien, E.K., 2017. Role of heat shock proteins in livestock adaptation to heat stress. J. Dairy Vet. Anim. Res., 5: 1-8.

Babar, M.E., Hussain, T., Wajid, A., Nawaz, A., Nadeem, A., Shah, S.A., Shahid, M.A., Ahmad, N., Javed, K. and Abdullah, M., 2015. Mitochondrial cytochrome-b and d-loop sequence based genetic diversity in Mareecha and Bareela camel breeds of Pakistan. J. Anim. Pl. Sci., 25: 591-594.

Babar, M.E., Hussain, T., Sadia, H., Nadeem, A., Kamran, M.Z. and Badshah, N., 2014. Mitochondrial Cytochrome B gene based phylogeny of Lohi and Thalli sheep breeds of Pakistan. J. Anim. Pl. Sci., 24: 1260-1262.

Banerjee, D., Upadhyay, R.C., Chaudhary, U.B., Kumar, R., Singh, S., Ashutosh, G.J.M., Polley, S., Mukherjee, A., Das, T.K. and De, S., 2014. Seasonal variation in expression pattern of genes under HSP70: Seasonal variation in expression pattern of genes under HSP70 family in heat- and cold-adapted goats (Capra hircus). Cell Stress Chaper., 19: 401-408. https://doi.org/10.1007/ s12192-013-0469-0

Chatterjee, S. and Burns T.F., 2017. Targeting heat shock proteins in cancer: A promising therapeutic approach. Int. J. mol. Sci., 18: 1-39. https://doi. org/10.3390/ijms 18091978

Dang, W., Xu, N., Zhang, W., Gao, J., Fan, H. and Lu, H., 2018. Differential regulation of Hsp70 expression in six lizard species under normal and high environmental temperatures. Pakistan J. Zool., 50: 1043-1051. http://dx.doi.org/10.17582/ journal.pjz/2018.50.3.1043.1051

Datta, K., Rahalkar, K. and Dinesh, D.K., 2017. Heat shock proteins (Hsp): Classifications and its involvement in health and disease. J. Pharma. Care Hlth. Syst., 4: 1-3.

Daugaard, M., Rohde, M. and Jäättelä, M., 2007. The heat shock protein 70 family: Highly homologous proteins with overlapping and distinct functions. FEBS Lett., 581: 3702-3710. https://doi. org/10.1016/j.febslet.2007.05.039

de Jong, M.A., Wahlberg, N., van Eijk, M., Brakefield, P.M. and Zwaan, B.J., 2011. Mitochondrial DNA signature for range-wide populations of Bicyclus anynana suggests a rapid expansion from recent refugia. PLoS One, 6: e21385. https://doi. org/10.1371/journal.pone.0021385

Edgar, R.C., 2004. MUSCLE: Multiple sequence alignment with high accuracy and high throughput. Nucl. Acids Res., 32: 1792-1797. https://doi. org/10.1093/nar/gkh340

Edkins, A.L., Price, J.T., Pockley, A.G. and Blatch, G.L., 2018. Heat shock proteins as modulators and therapeutic targets of chronic disease: An integrated perspective. Phil. Trans. R. Soc. Lond. B: Biol. Sci., 373: 1-7. https://doi.org/10.1098/rstb.2016.0521

Feder, M.E. and Hofmann, G.E., 1999. Heat-shock proteins, molecular chaperones, and the stress response: Evolutionary and ecological physiology. Annu. Rev. Physiol., 61: 243-282. https://doi. org/10.1146/annurev.physiol.61.1.243

Gade, N., Mahapatra, R.K., Sonawane, A., Singh, V.K., Doreswamy, R. and Saini, M., 2010. Molecular characterization of heat shock protein 70-1 gene of goat (Capra hircus). Mol. Biol. Int., 2010: 1-7. https://doi.org/10.4061/2010/108429

Gupta, R.S. and Singh, B., 1994. Phylogenetic analysis of $70 \mathrm{kD}$ heat shock protein sequences suggests a chimeric origin for the eukaryotic cell nucleus. Curr. Biol., 4: 1104-1114. https://doi.org/10.1016/ S0960-9822(00)00249-9

Gupta, S., Rao, A.R., Varadwaj, P.K., De, S. and Mohapatra, T., 2015. Extrapolation of inter domain communications and substrate binding cavity of camel HSP70 1A: A molecular modeling and dynamics simulation study. PLoS One, 10: 1-23. https://doi.org/10.1371/journal.pone.0136630

Gan, J.K., Jiang, L.Y., Kong, L.N., Zhang, X.Q. and Luo, Q.B., 2015. Analysis of genetic diversity of the heat shock protein 70 gene on the basis of abundant sequence polymorphisms in chicken breeds. Genet. Mol. Res., 14: 1538-1545. https:// doi.org/10.4238/2015.March.6.1

Hall, T.A., 1999. BioEdit: A user-friendly biological sequence alignment editor and analysis program for Windows 95/98/NT. Nucl. Acids Symp. Ser., 41: 95-98.

Hendrick, J.P. and Hartl, F.U., 1993. Molecular chaperone functions of heat-shock proteins. Annu. Rev. Biochem., 62: 349-384. https://doi. org/10.1146/annurev.bi.62.070193.002025

Hussain, T., Babar, M.E., Nadeem, A., Jabeen, R. and Ali, A., 2009. Phylogenetic analysis of kundi buffalo breed of Pakistan through mitochondrial D-loop region. Pakistan J. Zool., 9: 341-346.

Hussain, T., Babar, M.E., Sadia, H., Shaheen, M., Nadeem, A., Ali, A., Wajid, A. and Shah, S.A., 2013. Microsatellite markers based genetic diversity analysis in Damani and Nachi goat breeds of Pakistan. Pak. Vet. J., 33: 520-522. 
Hussain, T., Manzoor, M.M., Wajid, A., Nadeem, A., Ali, A., Shah, S.A., Abbas, K., Nawaz, A., Donato, M.de. and Babar, M.E., 2013a. High conservation of SRY gene in buffalo compared to other bovids. Buffalo Bull., 32: 666-670.

Hussain, T., Manzoora, M.M., Babar, M.E., Javed, M. and Nadeem, A., 2015. Comparative analysis of highly conserved $Z F X$ gene sequences of Pakistani river buffalo (Bubalus bubalis) with other bovids. J. Anim. Pl. Sci., 25: 884-887.

Jiang, P., Lang, Q., Fang, S., Ding, P. and Chen, L., 2005. A genetic diversity comparison between captive individuals and wild individuals of Elliot's Pheasant (Syrmaticus ellioti) using mitochondrial DNA. J. Zhejiang Univ. Sci. B, 6: 413-417. https:// doi.org/10.1631/jzus.2005.B0413

Karlin, S. and Brocchieri, L., 1998. Heat shock protein 70 family: Multiple sequence comparisons, function and evolution. J. mol. Evol., 47: 565-577. https://doi.org/10.1007/PL00006413

Kimura, M., 1984. The neutral theory of molecular evolution. Cambridge University Press.

Librado, P. and Rozas, J., 2009. DnaSP v5: A software for comprehensive analysis of DNA polymorphism data. Bioinformatics, 25: 1451-1452. https://doi. org/10.1093/bioinformatics/btp187

Kumar, A., Ashraf, S., Goud, T.S., Grewal, A., Singh, S.V., Yadav, B.R. and Upadhyay, R.C., 2015. Expression profiling of major heat shock protein genes during different seasons in cattle (Bos indicus) and buffalo (Bubalus bubalis) under tropical climatic condition. J. Therm. Biol., 51: 5564. https://doi.org/10.1016/j.jtherbio.2015.03.006

Langille, B., O’Leary, K., Whitney, H. and Marshall, H., 2014. Mitochondrial DNA diversity and phylogeography of insular Newfoundland red foxes (Vulpes vulpes deletrix). J. Mammal., 95: 772-780. https://doi.org/10.1644/13-MAMM-A-221

Li, Z. and Srivastava, P., 2004. Heat-shock proteins. Curr. Protoc. Immunol., Appendix 1: Appendix 1T.

Parsell, D.A. and Lindquist, S., 1993. The function of heat-shock proteins in stress tolerance: Degradation and reactivation of damaged proteins. Annu. Rev. Genet., 27: 437-496. https://doi.org/10.1146/ annurev.ge.27.120193.002253

Pawar, H.N., Agrawal, R.K., Verma, R. and Brah, G.S., 2013. Expression, purification and characterization of recombinant heat shock protein 70 (HSP70) from sheep and goat species. Int. J. Curr. Microbiol. appl. Sci., 2: 440-452.

Ravaschiere, A., Cutler, C., Edleson, K., Halem, Z., Magun, H., Meckler, F. and Cox, R., 2017.
Quantification of heat shock protein 70 and acetylcholinesterase over a time course suggests environmental adaptation in a foundational molluscan species. Ecotoxicol. environ. Safe., 142: 222-229. https://doi.org/10.1016/j. ecoenv.2017.04.003

Romero, R.D., Pardo, A.M., Montaldo, H.H., Rodríguez, A.D. and Cerón, J.H., 2013. Differences in body temperature, cell viability, and HSP-70 concentrations between Pelibuey and Suffolk sheep under heat stress. Trop. Anim. Hlth. Prod., 45: 16911696. https://doi.org/10.1007/s11250-013-0416-1

Rozas, J., Sánchez-DelBarrio, J.C., Messeguer, X. and Rozas, R., 2003. DnaSP, DNA polymorphism analyses by the coalescent and other methods. Bioinformatics, 19: 2496-2497. https://doi. org/10.1093/bioinformatics/btg359

Schmitt, E., Gehrmann, M., Brunet, M., Multhoff, G. and Garrido, C., 2007. Intracellular and extracellular functions of heat shock proteins: Repercussions in cancer therapy. J. Leukoc. Biol., 81: 15-27. https:// doi.org/10.1189/jlb.0306167

Shackleton, D.M. (ed.) and The IUCN/SSC Caprinae Specialist Group, 1997. Wild sheep and goats and their relatives. Status survey and conservation action plan for caprinae. IUCN, Gland, Switzerland and Cambridge, UK.

Sharma, S., Ramesh, K., Hyder, I., Uniyal, S., Yadav, V.P., Panda, R.P., Maurya, V.P., Singh, G., Kumar, P., Mitra, A. and Sarkar, M., 2013. Effect of melatonin administration on thyroid hormones, cortisol and expression profile of heat shock proteins in goats (Capra hircus) exposed to heat stress. Small Rumin. Res., 112: 216-223. https://doi. org/10.1016/j.smallrumres.2012.12.008

Tajima, F., 1983. Evolutionary relationship of DNA sequences in finite populations. Genetics, 105: 437 460.

Tajima, F., 1989. Statistical method for testing the neutral mutation hypothesis by DNA polymorphism. Genetics, 123: 585-595.

Tamura, K., Stecher, G., Peterson, D., Filipski, A. and Kumar, S., 2013. MEGA6: Molecular evolutionary genetics analysis version 6.0. Mol. biol. Evol., 30: 2725-2729. https://doi.org/10.1093/molbev/mst197

Yamada, K., Ansari, M., Harrington, R., Morgan, D. and Burgman, M.A., 2004. Sindh ibex (Capra aegagrus blythi) in Kirthar National Park, Pakistan: Sensitivity of a habitat and population model. In: Species conservation and management: Case studies (eds. H.R. Akçakaya, M.A. Burgman, O. Kindvall, C.C. Wood, P. Sjögren-Gulve, J.S. 
Hatfield and M.A. McCarthy). OUP, New York, pp. 469-481.

Wu, H. and Fang, S., 2005. Mitochondrial DNA genetic diversity of black muntjac (Muntiacus crinifrons), an endangered species endemic to China. Biochem. Genet., 43: 407-416. https://doi.org/10.1007/ s10528-005-6779-X

Zuo, D., Subjeck, J. and Wang, X.Y., 2016. Unfolding the role of large heat shock proteins: New insights and therapeutic implications. Front. Immunol., 7: 1-15. https://doi.org/10.3389/fimmu.2016.00075 